\title{
REPRODUCTIVE SEASONALITY OF FISHES FROM A LOTIC STRETCH OF THE GRANDE RIVER, HIGH PARANÁ RIVER BASIN, BRAZIL
}

\author{
ANDRADE, P. M. ${ }^{1}$ and BRAGA, F. M. S. ${ }^{1}$ \\ ${ }^{1}$ Dep. de Zoologia, Instituto de Biociências - UNESP, Campus de Rio Claro, CEP 13506-900, Rio Claro, SP \\ Correspondence to: Pedro de M. Andrade, Dep. de Zoologia, Instituto de Biociências - UNESP, \\ Campus de Rio Claro, Av. 24A, no 1515, Bela Vista, CEP 13506-900, Rio Claro, SP, \\ e-mail: pedrock_br@yahoo.com \\ Received September 11, 2003 - Accepted February 16, 2004 - Distributed August 31, 2005
}

(With 1 figure)

\begin{abstract}
We searched for correlations between water level, rainfall, temperature, and reproductive activity of fishes in a lotic stretch of the Grande River below the Volta Grande Dam. Gillnets were used to catch the fish on six field journeys made bimonthly between April 1998 and February 1999. Fish gonads were classified according to maturation grade and the amount of mature or spent gonads was correlated with rainfall and air temperature. Most fish species showed seasonal reproduction (between October and February). The relative frequency of fully mature and spent gonads significantly correlated with rainfall (Spearman $r=0.94, p=0.005)$ and air temperature $(r=0.84, p=0.036)$, showing the importance of these factors in regulating the reproductive cycle of fishes in this location. Nevertheless, dam operation resulted in minimal water level variation that did not significantly correlate with reproductive activity $(\mathrm{r}=-0.43, \mathrm{p}=0.396)$.
\end{abstract}

Key words: fish, reproduction, seasonality.

\section{RESUMO}

Sazonalidade reprodutiva de peixes de um trecho lótico do rio Grande, na bacia do alto rio Paraná

Foi investigada a correlação entre nível hidrológico, pluviosidade e temperatura e reprodução de peixes num trecho lótico do rio Grande, abaixo da barragem de Volta Grande. Para a captura, realizada com redes de espera, foram feitas seis amostragens bimestrais de abril de 1998 a fevereiro de 1999. As gônadas foram classificadas de acordo com o estádio de maturação e aquelas maduras ou esgotadas foram correlacionadas com as variáveis ambientais. A maioria das espécies apresentou reprodução sazonal, entre outubro e fevereiro. A freqüência relativa bimestral de gônadas maduras ou esgotadas de todos os exemplares agrupados foi correlacionada significativamente com pluviosidade (Spearman $\mathrm{r}=0,94, \mathrm{p}=0,005)$ e temperatura do ar $(\mathrm{r}=0,84, \mathrm{p}=0,036)$, mostrando a importância destes fatores no controle do ciclo reprodutivo dos peixes. Devido à barragem, o nível hidrológico pouco variou e não foi encontrada correlação significativa entre reprodução e nível hidrológico $(r=-0,43, p=0,396)$.

Palavras-chave: peixes, reprodução, sazonalidade. 


\section{INTRODUCTION}

Life-cycle characteristics such as reproduction seasonality of different fish species are regulated by environmental cues. In environments that are clearly defined seasonally, reproductive activity of several fish species is restricted to a specific annual period (Bye, 1984). The synchrony between reproduction onset and environmental cures depends on good dissolved-oxygen conditions, nutrient availability in the early growth periods and minimal risk of predation to the offspring (Vazzoler, 1996).

In the tropics, seasonal floodings are among the main reproduction cues for a great number of fish species. In the Amazon region, for example, there are two annual high-water periods. In the Paraná river basin the high-water season peaks in the summer months, with displacements for reproduction occurring in several fish species (Lowe-McConnel, 1999). In a highly cited paper, Godoy (1967) described a mark/ recapture project focused on migratory characins and pimelodids that was carried out in the Mogi-PardoGrande river system. The author located the reproductive areas in the high Mogi River; the feeding ground was mainly in the middle Grande River.

In contrast, the Paraná river basin, mainly in the middle and upper parts, is one of the most environmentally altered in Brazil. All of the ma- jor rivers in this basin have been dammed for electric energy production. Consequent impacts on the ichthyofauna have been identified by Petrere Jr. (1989); others, which have yet to be investigated are temporary or permanently lowered water levels and impeded reproductive migration.

Little is known about the life-cycle characteristics of several fish species in rivers that have cascaded reservoir systems. Therefore, the present work sought correlations between water level, rainfall, temperature, and reproductive activity of the most common fish species in a lotic stretch of the Grande River in the upper Paraná basin. This river, which because it is the most dammed in Brazil, provides favorable conditions for studying fish lifecycles. Before joining the Paranaíba River, it extends approximately 1,300 kilometers from its headwaters in the city of Bocâina de Minas.

\section{MATERIAL AND METHODS}

Samplings carried out below the Volta Grande dam in a stretch of the Grande River between latitudes $19^{\circ} 57^{\prime} 52^{\prime \prime}$ e $20^{\circ} 10^{\prime} 00^{\prime \prime}$ and longitudes $48^{\circ}$ $25^{\prime}$ and $47^{\circ} 35^{\prime}$ ' (Fig. 1). The Koeppen classification in this area is Aw, with dry season in winter (JuneSeptember). In summer (December-March), low air pressures make the season rainy.

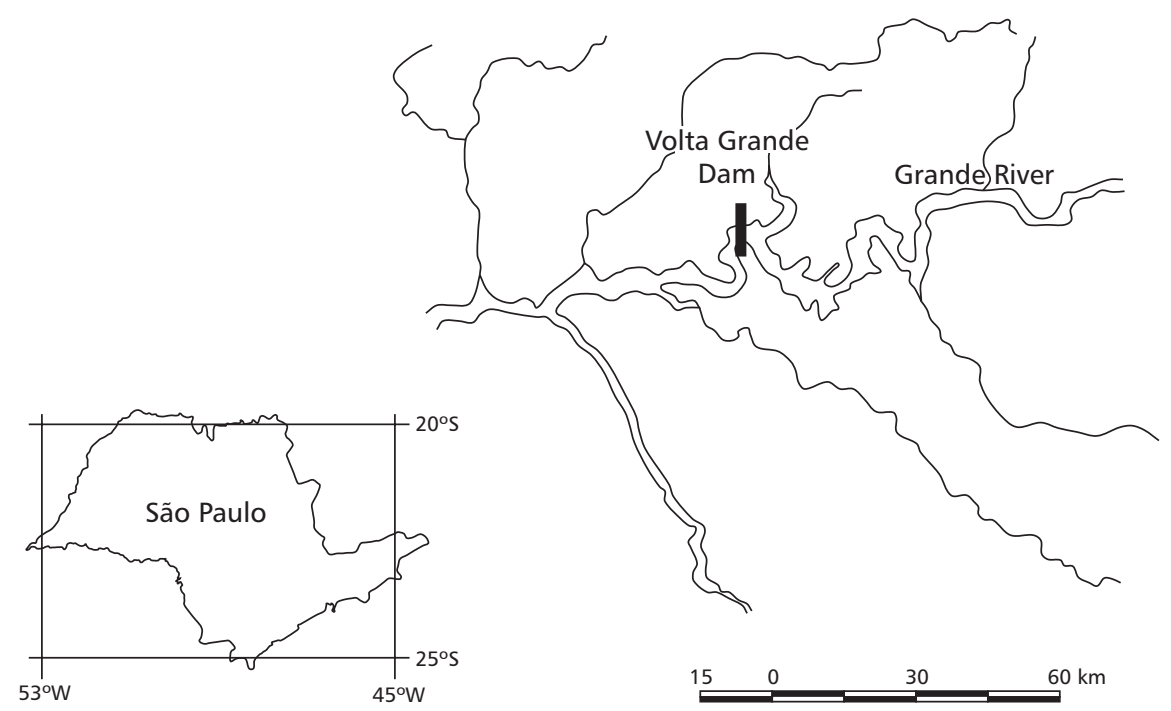

Fig. 1 - Map showing the sampling site, below the Volta Grande dam. In the detail one can see the location of the dam in the Grande river and the location of the area in the São Paulo/Minas Gerais border. 
Six bimonthly trips were made over a year. To capture the fish we used $150 \mathrm{~m}$ gillnets, $1 \mathrm{~m}$ high, of different sizes $(2,3,4,5$, and $6 \mathrm{~cm}$ between adjacent knots) and $1.5 \mathrm{~m}$ in height, totaling 750 meters. Another $800 \mathrm{~m}$ set, 2.5 in height with $8 \mathrm{~cm}$ between adjacent knots was used to capture larger fishes. In each sampling the gillnets were set up for 48 hours and checked every 12 . The fishes caught were boxed on ice and taken to the laboratory where the data were collected.

The fish were identified and dissected for macroscopically verifying the gonad maturation degree by the following gonadal structural features: color, size, transparency, vascularization, and ovocite presence. Gonads were classified as immature (A), dormant or in early maturation $(\mathrm{B})$, mature $(\mathrm{C})$, and spent (D).

To verify the reproductive season beginning and duration, relative frequencies of the different gonadal maturation states were determined for each sample $(n=6)$. The reproductive period was defined as that presenting the highest relative frequencies of mature or spent gonads.

The rainfall, air temperature, and water-level data were obtained from the Departamento de Programações e Ações Ambientais of the Companhia Energética de Minas Gerais (CEMIG) for the Usina Eléctrica de Volta Grande. Using Spearman rank these variables were correlated for the relative frequencies of $\mathrm{C}$ and $\mathrm{D}$ gonadal maturation classes for all fishes pooled, classifying females and males separately, and for some species that were sufficiently abundant during the sampling period to yield consistent information.

\section{RESULTS}

Fish captured numbered 1202 individuals from 29 species, 11 families, and 3 orders. The most abundant species were the characiforms Serrasalmus spilopleura, Prochilodus lineatus, and Schizodon nasutus; the siluriforms Pimelodus maculatus, Loricaria prolixa, and the perciform Plagioscion squamosissimus; these species appeared throughout the year. Others, such as Cichla ocellaris and Cichla monoculus, Cichlasoma fascetum, Leporinus friderici, Leporinus octofasciatus, and Megalancistrus aculeatus were found in all but one or two samples; the remaining species appeared sporadically. Table 1 contains a data summary on the fish sampled.
The rainfall, air temperature, and water level data appear in Table 2. As shown, air temperature and rainfall varied together, which was expected for this region. A $0.53 \mathrm{~m}$ water-level change caused by flux regulation of the dam was registered during the year.

Tables 3, 4, and 5 present percentages of individuals with mature or spent gonads in each monthly sample.

Table 6 includes Spearman rank correlations between fishes with mature or spent gonads and the environmental variables measured.

In conclusion, the highest frequencies of mature and spent gonads of the majority of the species were observed from October to early March (the rainy season).

\section{DISCUSSION}

Our results are best described by correlating the reproductive modes of captured fish with the reproductive guilds proposed by Agostinho \& Júlio Jr. (1999) who ascribed fish species to four groups according to reproductive characteristics. L. prolixa e $S$. spiloplerura, the most abundant species in our sampling, showed some degree of parental care and made no reproductive migrations; while not migrating for reproduction either, S. nasutus, the third most abundant species, presented no parental care behavior. Fish that are larger and belong to migratory species were not abundant, as had already been observed in the upper and middle Paraná river stretches.

In the reproductive season, which extended from October to February, the highest frequencies of fish in reproductive activity were registered in December. For characiforms, Vazzoler \& Menezes (1992) found that in October fish reproductive activity started in the Paraná river basin, and in December and February most species were reproducing. In this season the water level rises, which in the tropics is one of the main cues for several fish species to begin reproduction.

However, the water level showed very little variation and no correlation with gonadal maturation patterns. Seasonal variations in the water level have been drastically reduced owing to hydroelectrical plant operation (more than ten dams exist along the Grande River) and floodings are no longer common. 
TABLE 1

Species of fish captured from April-1998 to February-1999 below the Volta Grande Dam.

\begin{tabular}{|c|c|c|c|c|}
\hline Species & Family & SLmin & SLmax & Biomass (kg) \\
\hline Schizodon nasutus Kner, 1858 & Anostomidae & 14.2 & 37.5 & 66.18 \\
\hline Leporinus friderici Bloch, 1794 & Anostomidae & 13.7 & 32.2 & 11.06 \\
\hline Leporinus elongatus Valenciennes, 1849 & Anostomidae & 29.2 & 39.8 & 7.73 \\
\hline Leporellus vittatus Valenciennes, 1849 & Anostomidae & 25 & 28.9 & 0.813 \\
\hline Leporinuslacustris Campos, 1945 & Anostomidae & 12.3 & 12.3 & 0.056 \\
\hline Leporinus octofasciatus Steindachner, 1917 & Anostomidae & 16.1 & 25.3 & 7.16 \\
\hline Serrasalmus spilopleura Kner, 1858 & Characidae & 6.4 & 25 & 21.34 \\
\hline Myleus tiete Eigenmann \& Norris, 1900 & Characidae & 8.9 & 16.3 & 2.12 \\
\hline Astyanax altiparanae Garutti \& Britsky, 2000 & Characidae & 9.5 & 10.6 & 0.137 \\
\hline Astyanax fasciatus Cuvier, 1819 & Characidae & 8 & 12 & 0.387 \\
\hline Salminus maxillosus Valenciennes, 1840 & Characidae & 35.6 & 35.6 & 0.843 \\
\hline Galeocharax knerii Steindachner, 1879 & Characidae & 18.9 & 21.5 & 0.615 \\
\hline Hoplias ma/abaricus Bloch, 1794 & Erythrinidae & 26 & 26 & 0.199 \\
\hline Hoplias lacerdae Ribeiro, 1908 & Erythrinidae & 21.5 & 53 & 11 \\
\hline Apareiodon piracicabae Eigenmann, 1907 & Parodontidae & 9 & 12 & 0.125 \\
\hline Prochilodus lineatus Valenciennes, 1836 & Prochilodontidae & 24.6 & 61.5 & 246 \\
\hline Loricaria prolixa lentiginosa Insbrucker, 1978 & Loricariidae & 20.7 & 51.4 & 112.34 \\
\hline Mega/ancistrusparananus Peters, 1881 & Loricariidae & 21.4 & 58.8 & 49.74 \\
\hline Hypostomus sp. 1 & Loricariidae & 20 & 49.3 & 12.78 \\
\hline Hypostomus sp. 2 & Loricariidae & 22.9 & 44.8 & 8.98 \\
\hline Pimelodus maculatus Lacepede, 1803 & Pimelodidae & 11.2 & 36.8 & 36.14 \\
\hline Pinirampus pirinampu Spix \& Agassiz, 1829 & Pimelodidae & 44 & 57.5 & 18.05 \\
\hline Rhinodoras dorbigny Kner, 1855 & Doradidae & 9.7 & 14.7 & 0.189 \\
\hline Plagioscion squamosissimus Heckel, 1840 & Scienidae & 15.4 & 51.5 & 57.34 \\
\hline Cichlasoma facetum Jenyns, 1842 & Cichlidae & 8.2 & 19.3 & 9.86 \\
\hline Cichla ocellaris Bloch \& Schneider, 1801 & Cichlidae & 10.5 & 39 & 35.9 \\
\hline Cichla monoculus Spix \& Agassiz, 1831 & Cichlidae & 9.9 & 38 & 6.29 \\
\hline Tilapia rendalli Boulanger, 1897 & Cichlidae & 28.5 & 36 & 13.48 \\
\hline Crenicichla britskii Kullander, 1982 & Cichlidae & 8.3 & 14.5 & 0.024 \\
\hline
\end{tabular}

SL: Standard lenght.

Environmental factors produce different effects according to the phase of the reproductive cycle, and have possible long-term effects on gonadal tissue growth and short-term effects on oocyte maturation and release (Stacey, 1984). They influence gonadal development phases, synchronize processes involved in final gamete maturation, signal ideal conditions for spawning, and end reproductive activity (Vazzoler, 1996).
In our study the most important synchronizing factor was rainfall intensity; this was inferred by the correlations between rainfall and reproductivity, either with the captured fish grouped together or by sex. Lowe-McConnel (1999) had already observed that in tropical regions spawning is stimulated by local rains or by a raising water level in the entire basin. 
TABLE 2

Air temperature (T), rainfall (mm), and water level (meters above sea level) during one year of sampling in the Volta Grande dam area.

\begin{tabular}{|c|c|c|c|}
\hline Month & $\mathbf{T}\left({ }^{\mathbf{0}} \mathbf{C}\right)$ & Water level $(\mathbf{m})$ & Pluviometer $(\mathbf{m m})$ \\
\hline April & 26.6 & 446.48 & 102.4 \\
\hline June & 21.9 & 466.67 & 1.3 \\
\hline August & 23.5 & 466.73 & 55.6 \\
\hline October & 27.0 & 466.35 & 226.5 \\
\hline December & 28.8 & 466.64 & 321.5 \\
\hline February & 28.5 & 466.88 & 135.0 \\
\hline
\end{tabular}

TABLE 3

Monthly percentages of fishes with full mature or spent gonads by sampling month.

\begin{tabular}{|l|c|c|c|c|c|c|}
\hline \multicolumn{1}{|c|}{ Species } & April & June & August & October & December & February \\
\hline M. parananus & & & & 61.1 & 80.0 & 90.0 \\
\hline C. facetum & 17.5 & & & & 25 & 77.8 \\
\hline L. prolixa lentiginosa & 61.1 & 15.4 & 29.2 & 68.3 & 76.9 & 4.8 \\
\hline P. squamosissimus & 2.6 & & & & 14.3 & 12.5 \\
\hline P. lineatus & & & & 20 & 100 & 66.7 \\
\hline P. maculatus & & & & 44.5 & 5.9 & \\
\hline S. spilopleura & 1.5 & 2.8 & & 5.6 & 51.3 & 3.8 \\
\hline S. nasutus & 11.1 & 11.8 & 45.5 & 52.1 & 87.0 & 75.0 \\
\hline L. octofasciatus & 50.0 & 50.0 & & 100.0 & & 64.3 \\
\hline M. tyete & & & & & & 50.0 \\
\hline L. friderici & 25.0 & & & & & \\
\hline H. lacerdae & & & & & & \\
\hline C. cf. ocellaris & 6.3 & & 100.0 & & 11.1 & 26.7 \\
\hline C. cf. monoculus & 100.0 & & & & & 50.0 \\
\hline
\end{tabular}

Like the results of Braga (1990), who found a close relationship between seasonal variations in environmental conditions and fish reproduction and feeding in the Tocantins River in the Amazon basin, our study showed that the reproductive period of fish species were synchronized by the abundant rains in the summer months. These were designated as the reproduction period for $P$. squamosissimus by
Braga (1997), for Leporinus reinhardti by Rizzo et al. (1996), and for Schizodon knerii by Ferreira \& Godinho (1990).

As a result of working in tributaries of the Volta Grande Reservoir, Braga (2001) verified that the highest reproductive period was in summer, with December registering the highest value in the reproductive activity index. 
TABLE 4

Monthly percentages of females with full mature or spent gonads by sampling month.

\begin{tabular}{|l|c|c|c|c|c|c|}
\hline \multicolumn{1}{|c|}{ Species } & April & June & August & October & December & February \\
\hline M. parananus & & & & 33.0 & 66.0 & \\
\hline R. dorbigny & & & & & 33.0 & 66.0 \\
\hline C. facetum & 62.0 & & & & 12.0 & 24.0 \\
\hline Loricaria prolixa lentiginosa & 20.0 & 23.0 & 9.0 & 14.0 & 18.0 & 16.0 \\
\hline P. squamosissimus & 100.0 & & & & & \\
\hline P. lineatus & & & & 60.0 & 20.0 & 20.0 \\
\hline L. octofasciatus & 7 & & & 7.0 & 64.0 & 21.0 \\
\hline C. britskii & & 100.0 & & & & \\
\hline A. fasciatus & & & & & 92.0 & 8.0 \\
\hline P. maculatus & & & & 17.0 & 42.0 & 42.0 \\
\hline M. tyete & & & & & & 100.0 \\
\hline L. friderici & 33.0 & & & & & 66.0 \\
\hline S. spilopleura & 25.0 & 25.0 & & 25.0 & 25.0 & \\
\hline L. vittatus & & & & & & 100.0 \\
\hline S. nasutus & 12.5 & 8.0 & 17.0 & 29.0 & 25.0 & 8.0 \\
\hline H. lacerdae & & & & 50.0 & 50.0 & \\
\hline C. ocellaris & & & & 100.0 & & \\
\hline C. monoculus & 100.0 & & & & & \\
\hline
\end{tabular}

TABLE 5

Monthly percentages of males with full mature or spent gonads by sampling month.

\begin{tabular}{|l|c|c|c|c|c|c|}
\hline \multicolumn{1}{|c|}{ Species } & April & June & August & October & December & February \\
\hline M. parananus & & & & 69.0 & 31.0 & \\
\hline R. dorbigny & & & & & & 100.0 \\
\hline C. facetum & 22.0 & & & & & 77.0 \\
\hline L. prolixa lentiginosa & 5.0 & 2.0 & 8.0 & 58.0 & 5.0 & 19.0 \\
\hline P. squamosissimus & & & & & & \\
\hline P. lineatus & & & & & & \\
\hline L. octofasciatus & 14.0 & & & 7.0 & 78.0 & \\
\hline A. Bimaculatus & & & & & 100.0 & \\
\hline P. maculatus & & & & 86.0 & & 14.0 \\
\hline L. elongatus & & & & 100.0 & & \\
\hline S. nasutus & & & 6.0 & 31.0 & 62.0 & \\
\hline H. lacerdae & & & & & & \\
\hline C. ocellaris & 100.0 & & & & & \\
\hline C. monoculus & 100.0 & & & & & \\
\hline
\end{tabular}


TABLE 6

Results from Spearman rank correlation between fishes with full mature or spent gonads and environmental variables. The results are showed for all individuals pooled (Females + Males), all males or females pooled (M or F) and for some of the most abundant species.

\begin{tabular}{|c|c|c|c|}
\hline & Variable & Spearman $\mathbf{~}$ & $\mathbf{p}$ \\
\hline Females + Males & pluviosity & 0.94 & $<0.005$ \\
\hline $\mathrm{F}+\mathrm{M}$ & temperature & 0.84 & $<0.036$ \\
\hline $\mathrm{F}$ & pluviosity & 0.89 & $<0.019$ \\
\hline $\mathrm{F}$ & temperature & 0.94 & $<0.008$ \\
\hline $\mathrm{M}$ & pluviosity & 0.94 & $<0.005$ \\
\hline $\mathrm{M}$ & temperature & 0.75 & $<0.080$ \\
\hline $\mathrm{F}+\mathrm{M}$ & water level & -0.43 & $<0.396$ \\
\hline $\mathrm{M}$ & water level & -0.49 & $<0.329$ \\
\hline $\mathrm{F}$ & water level & -0.14 & $<0.787$ \\
\hline L. prolixa & pluviosity & 0.26 & $<0.620$ \\
\hline S. nasutus & pluviosity & 0.70 & $<0.120$ \\
\hline L. prolixa & temperature & 0.13 & $<0.800$ \\
\hline S. nasutus & temperature & 0.44 & $<0.380$ \\
\hline P. maculatus & pluviosity & 0.83 & $<0.040$ \\
\hline
\end{tabular}

The most seasonal behavior was presented by P. maculatus, a very common species in the reservoirs of southeastern Brazil, and represents a considerable part of the commercial catch as revealed by surveys made by Braga \& Gomiero (1997), CESP (1993, 1996), and in a review by Petrere Jr. (1993). Godinho et al. (1977) showed that this species carried out successive spawnings between December and February. In addition, Braga (2000) found that the occurrence of mature and spent $P$. maculatus in the Volta Grande Reservoir was more intense during the months of October to February.

However, we observed species like $S$. nasutus who exhibited no pronounced seasonal reproductive behavior. Barrela (1997) related that the extensive macrophyte beds below the Três Irmãos Reservoir could be favoring some species, among them $S$. nasutus. Macrophyte bed formation below dams was also commented on by Stanford \& Ward (apud Allan, 1995), who noted that the increased water transparency caused by sediment retention and reduced water flux caused by dams usually results in a great abundance of periphyton and superior plants is found downstream. A relationship between food supply and fecundity was observed by Nikolfski (1969). In addition, Jobling (1994) observed that when food supply decreases, fewer individuals show gonadal development. Verifying empirically if the contrary is true would be possible in the case of $S$. nasutus, whose gonads are mature throughout the year, coinciding with year-round abundance of the aquatic macrophyte Egeria sp.

In the present study, individuals of Prochilodus lineatus with spent gonads were not captured. Petrere Jr. (1993) has pointed out that this species, caught principally between November and March, is one of the most important for commercial fisheries in the Grande River. But large migratory species are the most affected by the impoundments, mainly those obstructing their migratory routes. For example, that of $P$. lineatus goes through a multi-dam system, formed by the Pardo-Mogi-Grande rivers (Godoy, 1967), which is now fragmented. The populations of $P$. lineatus found between the Volta Grande and Porto Colombia dams have no access to the Pardo River, from which they formerly reached their spawning grounds in the Mogi (Godoy, 1967). Some mature individuals of $P$. lineatus were captured in 
October, December, and February, a period during which large schools of this species were observed near the dam. This behavior was also observed by Agostinho et al. (1993) who found that below the Itaipú Reservoir, large migratory species were unable to conclude spawning and showed atresic gonads.

In conclusion, in the stretch of the Grande River sampled, despite hydrological regime alteration, reproductive cycles in fish continue being regulated by responses to stimuli like rain intensity and temperature. However, seasonality is less pronounced in some species.

\section{REFERENCES}

AGOSTINHO, A. A. \& JÚLIO Jr., H. F., 1999, Peixes da bacia do alto Paraná. In: R. H. Lowe-McConnel, Estudos ecológicos de comunidades de peixes tropicais. EDUSP, São Paulo, cap. 16, pp. 374-399.

AGOSTINHO, A. A., MENDES, V. P., SUZUKI, H. I. \& CANZI, C., 1993, Avaliação da atividade reprodutiva da comunidade de peixes dos primeiros quilômetros a jusante do Reservatório de Itaipu. Rev. UNIMAR, 15(suplemento): 175-89.

ALLAN, J. D., 1995, Stream ecology: Structure and function of running waters. Chapman \& Hall, London, 388p.

BARRELA, W., 1997, Alterações das comunidades de peixes nas bacias dos Rios Tietê e Paranapanema (SP), devido a poluição e represamento. Tese de Doutorado, Instituto de Biociências, Universidade Estadual Paulista, Rio Claro, 115p.

BRAGA, F. M. S., 1990, Aspectos da reprodução e alimentação de peixes comuns em um trecho do rio Tocantins entre Imperatriz e Estreito, estados do Maranhão e Tocantins, Brasil. Rev. Bras. Biol., 50(3): 547-58.

BRAGA, F. M. S., 1997, Biologia reprodutiva de Plagioscion squamosissimus (Teleostei, Scienidae) na Represa de Barra Bonita, Rio Piracicaba (SP). Rev. UNIMAR, 19(2): 447-60.

BRAGA, F. M. S., 2000, Biologia e pesca de Pimelodus maculatus (Siluriformes, Pimelodidae), no reservatório de Volta Grande, rio Grande (MG-SP). Acta Limnol. Bras., 12: $1-14$.

BRAGA, F. M. S., 2001, Reprodução de peixes (OSTEICHTHYES) em afluentes do reservatório de Volta Grande, Rio Grande, Sudeste do Brazil. Iheringia, Sér. Zool., 91: $67-74$.

BRAGA, F. M. S. \& GOMIERO, L. M., 1997, Análise da pesca experimental realizada no reservatório de Volta Grande, Rio Grande, MG-SP. B. Inst. Pesca, 24(único): 131-38.

BYE, V. J., 1984, The role of environmental factors in the timing of reproductive cycles. In: Fish reproduction: strategies and tactics. G. W. Potts \& R. J. Wooton (eds.), London, Academic Press, cap. 11, pp. 187-205.
CESP, 1993, Produção pesqueira e composição das capturas em reservatórios sob concessão da CESP nos rios Tietê, Paraná e Grande no período de 1986 a 1991. / CESP; Carlos Eduardo Cappellini Torloni et al., 73p.

CESP - Aspectos limnológicos, ictiológicos e pesqueiros de reservatórios da CESP no período de 1986 a 1994, 1996. Série Pesquisa e Desenvolvimento, 136, 81p.

FERREIRA, R. M. A. \& GODINHO, H. P., 1990, Reproductive biology of the white-piau, Schizodon knerii (Steindachner, 1875) (Anostomidae) from a reservoir in southeast Brazil. Eur. Arch. Biol., 101: 331-44.

GODINHO, H. M. et al., 1977, Fecundidade e tipo de desova do mandi, Pimelodus maculatus Lacépède, 1803 (Pisces, Siluroidei). Rev. Brasil. Biol., 37(4): 737-44.

GODOY, M. P., 1967, Dez anos de observações sobre periodicidade migratória de peixes do Rio Mogi-Guassu. Rev. Brasil. Biol., 27(1): 1-12.

JOBLING, M., 1994, Biotic factors and growth performance. In: Fish Bioenergetics. $1^{\text {st }}$ ed. Chapman \& Hall, UK, pp. 169-201.

LOWE-McCONNELL, R. H., 1999, A fauna de peixes Neotropical. In: Estudos ecológicos de comunidades de peixes tropicais. $1^{\mathrm{a}}$ ed. Editora da Universidade de São Paulo (EDUSP), pp. 129-168.

NIKOLSKI, G. V., 1969, Fecundity, quality of the sex products and course of spawning. In: Fish population dynamics. Oliver \& Boyd, Edinburg, pp. 31-67.

PETRERE Jr., M., 1993, Comisión de Pesca Continental para América Latina. Informe de la Sexta reunión del grupo de trabajo sobre recursos pesqueros. Montevidéu, Uruguai, 1013 de maio de 1993. FAO Informe de Pesca. N. 490. Roma, FAO, 80p.

PETRERE Jr., M., 1989, River fisheries in Brazil: a review. Regulated Rivers: research and management, 4: 1-16.

RIZZO, E., SATO, Y., FERREIRA, R. M. A., CHIARINIGARCIA, H. \& BAZZOLI, N., 1996, Reproduction of Leporinus reinhardti Lutken, 1874 (Pisces:Anostomidae) from the Três Marias Reservoir, São Francisco River, Minas Gerais, Brazil. Ciência e Cultura, 48(3): 189-92.

STACEY, N. E., 1984, Control of timing of ovulation by exogenous and endogenous factors. In: G. W. Potts \& R. J. Wooton (eds.), Fish reproduction: strategies and tactics. London, Academic Press, chap. 12, pp. 207-222.

VAZZOLER, A. E. A. M., 1996, Biologia da reprodução de peixes teleósteos: teoria e prática. Maringá: EDUEM, 169p.

VAZZOLER, A. E. A. M. \& MENEZES, N. A., 1972, Síntese de conhecimentos sobre o comportamento reprodutivo dos characiformes da América do Sul (Teleostei, Ostariophysi). Rev. Bras. Biol., 52(4): 627-40. 